\title{
Traps and Baits for Luring Grapholita molesta (Busck) Adults in Mating Disruption-Treated Apple Orchards
}

\author{
AC PADILHA ${ }^{1,2}$, CJ ARIOLI ${ }^{3}$, MIC BofF $^{1}$, JM RosA ${ }^{1}$, M Botton $^{4}$ \\ ${ }^{1}$ Univ do Estado de Santa Catarina (UDESC), Centro de Ciências Agroveterinárias (CAV), Lages, SC, Brasil \\ ${ }^{2}$ Centro de Ciências Agrovetrinárias (CAV), Univ do Estado de Santa Catarina (UDESC), Lages, Santa Catarina, Brasil \\ ${ }^{3}$ Empresa de Pesquisa Agropecuária e Extensão Rural de Santa Catarina - Estação Experimental de São Joaquim, São Joaquim, SC, Brasil \\ ${ }^{4}$ Empresa Brasileira de Pesquisa Agropecuária - Embrapa Uva e Vinho, Bento Gonçalves, RS, Brasil
}

\section{Keywords}

Oriental fruit moth, terpinyl acetate, brown sugar, food bait, sex pheromone

\section{Correspondence \\ AC Padilha, Centro de Ciências Agrovetrinárias (CAV), Univ do Estado de Santa Catarina (UDESC), Avenida Luiz de Camões, 2090, Conta Dinheiro, Lages, 88520-000, Santa Catarina, Brasil; acostapadilha08@gmail.com}

Edited by G A Carvalho - UFLA

Received 6 July 2016 and accepted 20 March 2017

Published online: 4 April 2017

(C) Sociedade Entomológica do Brasil 2017

\begin{abstract}
Grapholita molesta (Busck) is one of the main pests in apple crops in Brazil, where it is controlled by mating disruption (MD) with the use of the synthetic sex pheromone. However, sex-pheromone-based monitoring is not effective in MD-treated areas and may result in losses in production. This work has defined a trap model and a bait for luring G. molesta adults in MD apple orchards. The experiments were conducted in commercial apple orchards located in São Joaquim, SC, Brazil. Three trap models-McPhail, Pot, and Ajar-and three baits-grape juice (25\%) (GJ), sugarcane molasses (25\%) (SM), and a solution containing brown sugar (8.69\%) and terpinyl acetate (0.05\%) (TAS) - were assessed for luring $G$. molesta adults in areas subjected to the mating disruption. The assessments were performed weekly by collecting the insects caught in the traps. In addition, time needed to replace traps was also assessed, as well as the selectivity of the trap/bait set. In the laboratory, G. molesta adults were sexed, and the females were dissected to confirm reproductive status. We discuss our results and sugarcane molasses (25\%) captured the least number of $G$. molesta adults regardless of the tested traps. The Ajar/TAS, Pot/TAS, and McPhail/GJ captured the largest number of G. molesta adults. The Ajar/TAS was the most selective and easier to handle. TAS was efficient in catching $G$. molesta until 14 days after preparation of the solution. Ajar/TAS has potential to be used in the monitoring of $G$. molesta in apple orchards.
\end{abstract}

\section{Introduction}

The oriental fruit moth, Grapholita molesta (Busck) (Lepidoptera: Tortricidae), is one of the main pests in apple crops, mainly in the states of Santa Catarina and Rio Grande do Sul, which are important fruit producers in Brazil (Nora \& Hickel 2006, Pastori et al 2012). The main tactic for control of G. molesta is the use of insecticides (Pim - Produção Integrada de Maçã 2015). However, there are restrictions on the use of some chemical groups, particularly in orchards cultivated under an Integrated Apple Production (Mapa
2013, Pim - Produção Integrada de Maçã 2015). In addition, Organic Fruit Production systems do not allow the use of synthetic insecticides.

An alternative to chemical control is the use of synthetic sex pheromones by means of mating disruption (MD). This technique consists of releasing a great amount of synthetic sex pheromone into the environment, so it saturates the surroundings and males are not able to orient toward the natural sex pheromone plume (Agosta 1990). This technique prevents females from being fertilized and hence reduces the future population of oriental moths (Cardé \& Minks 1995, Arioli et al 2013). 
In order to assess the efficacy of mating disruption technique as a control method, pest population must be monitored (Arioli et al 2013). This procedure is usually performed by monitoring pointers and fruits attacked in the field as well as using sex-pheromone baited traps (Arioli et al 2013). However, these monitoring methods seem not to be efficient or compatible with MD. Sampling pointers and fruits are time-consuming and demands skilled labor. Moreover, sexpheromone-based monitoring can have similar formulations as MD, and using both strategies are usually incompatible (Rice \& Kirsch 1990). Sex-pheromone based monitoring exclusively attracts males and does not detect the presence of females in the orchard, which may be fertilized and ready for oviposition (Howell 1991).

An alternative to monitoring of oriental moths, especially females, in areas treated with mating disruption is the use of traps containing food baits, such as sugarcane molasses, red wine vinegar, and fruit juice (Campos \& Garcia 2001, Strapasson 2012). Food baits have been used previously for monitoring $G$. molesta before the rise of sex pheromone for monitoring purposes (Yetter \& Steiner 1931, Dustan 1964). However, after identification and synthesis of pheromone traps (Phillips 1973), the use of these compounds decreased significantly because they have limitations such as low specificity of attraction, which hinders screening and identification of the target species (Botton et al 2001).

Studies of traps and baits for monitoring the oriental fruit moth have been conducted in different regions, in order to identify the best shape and color for the traps, the best method to catch insects (Kovanci et al 2005, Cichon et al 2013, Knight et al 2014) and selectivity to nontarget organisms such as bees (Knight et al 2013). The bait trap combination can significantly improve the monitoring efficiency for G. molesta in areas treated with MD. Thus, the present study was conducted to assess different models of food traps and baits aimed at defining the best set and bait replacement interval, seeking to establish a monitoring system for G. molesta in MD apple orchards.

\section{Material and Methods}

The experiments were conducted in São Joaquim, SC (latitude $28^{\circ} 16^{\prime}$ South, longitude $49^{\circ} 55^{\prime}$ West and approximate altitude of $1400 \mathrm{~m}$ ), between January and March 2014. For these experiments, three commercial apple orchards (A, B, and $C$ ) were selected. They have natural infestation of G. molesta and significant damage records in the 2012/2013 crop. In these orchards, plants of the cultivar 'Gala' (66\%) and 'Fuji' (33\%) with approximately 7 years of age were present, spaced at $2.5 \mathrm{~m} \times 6.0 \mathrm{~m}$ (plants $\times$ rows), with plants measuring approximately $4.0 \mathrm{~m}$ in height.

\section{Traps and baits}

Three trap models were assessed: (a) McPhail (Fig 1a) with $600 \mathrm{~mL}$ capacity, with a clear polycarbonate domed top and yellow polypropylene domed bottom, (b) Pot (Fig 1b) with $700 \mathrm{~mL}$ capacity, composed of a white bucket with a lid, measuring $20 \mathrm{~cm}$ in height and $20 \mathrm{~cm}$ in diameter, and (c) Ajar, adapted from Cichon et al (2013) (Fig 1c), built from a white delta trap model, $10.0 \mathrm{~cm}$ high $\times 19.5 \mathrm{~cm}$ wide and $28.4 \mathrm{~cm}$ long, with a sticky card insert (liner) measuring $385.3 \mathrm{~cm}^{2}$. The card was cut into a circle, forming a hole with $9 \mathrm{~cm}$ in diameter. A transparent, 700-mL plastic cup was attached to this hole for deposition of liquid bait.

A sticky liner was also cut in the center with the same diameter and placed on the background to allow the release of volatiles. To prevent contact between the insects and the liquid, the glass was covered with a voile fabric ( $20 \mathrm{~cm} \times 15 \mathrm{~cm}$ wide). The McPhail trap was tested because fruit growers have reported that they often find specimens
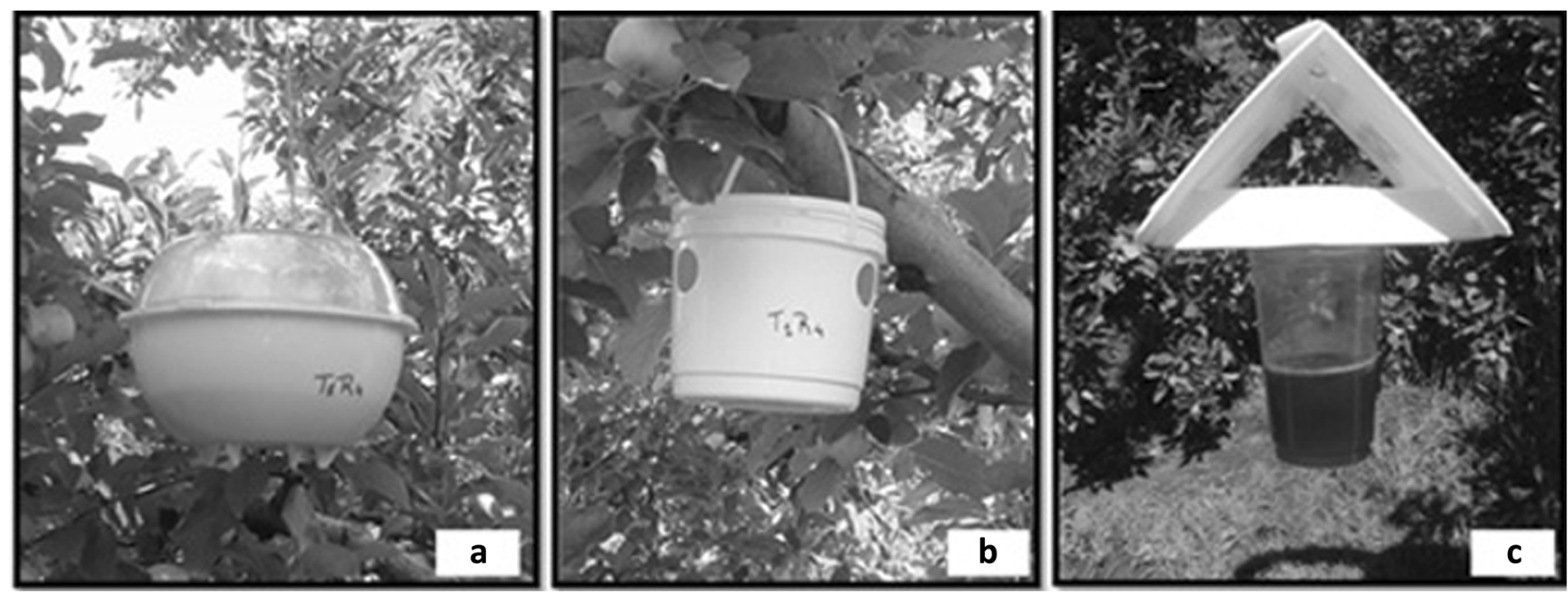

Fig 1 Trap models assessed for capture of Grapholita molesta adults in apple orchards: McPhail (a), Pot (b), and Ajar (c). São Joaquim, SC, Brazil. 
of G. molesta when using this bait with grape juice $25 \%$ for monitoring the South American fruit fly, Anastrepha fraterculus (Wiedemann) (Diptera: Tephritidae). In addition, it has been used in previous tests for monitoring G. molesta with food baits in Brazil (Campos \& Garcia 2001, Strapasson 2012). The pot trap was selected because a similar model was used for monitoring Lepidoptera with food baits in temperate fruit orchards (Evenden \& Mclaughlin 2004, Bagnoli et al 2013). The Ajar trap was chosen for its ability to capture insects on a sticky liner, so insects can soon be seen in the field (Cichon et al 2013).

The tested baits were attractant solutions: (a) whole grape juice (25\%) Horti-Fruti Carraro ${ }^{\circledR}$ Monte Alegre dos Campos, Brazil (GJ), (b) sugarcane molasses (25\%) Molinari ${ }^{\circledR}$ Palhoça, Brazil (SM), and (c) solution containing terpinyl acetate (0.05\%) BioFragane ${ }^{\circledR}$ Ponta Grossa, Brazil, plus brown sugar (8.69\%) Horti-Fruti Carraro ${ }^{\circledR}$ Monte Alegre dos Campos, Brazil, plus Tween 20 Sigma-Aldrich ${ }^{\circledR}$ Jurubatuba, Brazil (TAS). Containers intended to receive the baits in all the traps were filled with $300 \mathrm{~mL}$ of the respective attractants. The baits, grape juice, and sugarcane molasses were chosen because they are known for being attractive to adults of G. molesta (Campos \& Garcia 2001), while TAS proved to be effective and selective to nontarget species (Kovanci et al 2005, Cichon et al 2013, Knight et al 2014).

\section{Assessment of attractants and traps}

This experiment was conducted in three apple orchards: (a) orchard A (28 $17^{\prime} 38.21^{\prime \prime}$ S; $49^{\circ} 52^{\prime} 53.52^{\prime \prime}$ W), (b) orchard B (28 10'25" S; 5000'39" W), and (c) orchard C (28 $10^{\circ} 30^{\prime \prime} \mathrm{S}$; $\left.50^{\circ} 00^{\prime} 32^{\prime \prime} \mathrm{W}\right)$. In the three orchards, the mating disruption technique was used as a means of control of $G$. molesta. The three orchards received the application of synthetic sex pheromone in the Splat formulation (Splat Grafo ${ }^{\circledR}$ ) at $1 \mathrm{~kg} / \mathrm{ha}$ (Pastori et al 2012, Arioli et al 2014).

The treatments consisted of combinations of trap models and baits, and they were distributed in the orchards following an experimental randomized block design with four replications, in a $(3 \times 3)$ factorial arrangement. The trap-bait combinations formed nine treatments. Each plant row was considered as a block, and traps were interspaced at $20 \mathrm{~m}$, fixed on a plant branch at approximately $1.60 \mathrm{~m}$ aboveground level. For trap distribution in the area, two plant rows were determined as side borders.

\section{Bait persistence}

After defining the best trap/bait set (Ajar/TAS), in the previous experiment, bait persistence was tested in the orchard between February and March 2014. The bait (TAS) was prepared at predetermined intervals: on the day of the experiment, $3,7,14,21$, and 28 days before of the experiment, kept at room temperature in a $2 \mathrm{~L}$ Becker covered with voile fabric. Traps were evaluated at 7, 10, 14, 21, 28, and 35 days. Ajar traps containing the attractant at different aging times were distributed in the orchard and fixed on the branches of plants at approximately $1.60 \mathrm{~m}$ aboveground surface, interspaced at $20 \mathrm{~m}$. The experimental design was a randomized block design with four replications.

\section{Assessments and statistical analysis}

Trapped insects were collected and baits were replaced weekly. The insects caught in the Pot and McPhail traps were sifted and placed in collection jars, and then taken to the laboratory for further screening. The sticky liners removed from the traps were brought to the laboratory, and the insects were removed from the card by placing a drop of ink solvent on the insects. All captured $G$. molesta adults were separated and sexed, and the females were dissected for assessing whether they had been mated. A female was considered to have copulated when there was at least one spermatophore in the bursa copulatrix (Morais et al 2008).

Besides $G$. molesta individuals, numbers of trapped nontarget insects were recorded and separated by taxonomic order (Hymenoptera, Lepidoptera, Diptera, and others). All insects captured were taken to the Entomology Laboratory at Epagri - Experimental Station of São Joaquim for screening, where they were placed in Eppendorf ${ }^{\circledR}$ tubes and labeled with date, trap type, and collection site.

The data collected in the experiments were transformed into square root of $(x+0.5)$ and analyzed for normality and homogeneity. If data met parametric assumptions, they were analyzed by analysis of variance (ANOVA) and the means were compared by Tukey's test ( $p \leq 0.05)$ using the statistical software program $R$ version 3.1.0 ( $R$ : A language and environment for statistical computing 2014).

\section{Results}

\section{Traps and baits}

Numbers of captured oriental fruit moth significantly differed between the trap/bait sets in all the orchards used in study (Tables 1, 2, and 3). Sugarcane molasses as a bait in the three types of traps did not capture any $G$. molesta adults in orchard A. Ajar/TAS, Pot/TAS, and McPhail/GJ captured significantly more G. molesta adults than Pot/GJ and all the treatments with sugarcane molasses. In terms of female adults, Ajar/TAS trapped more individuals than most of the other treatments, while both Ajar/TAS and Pot/TAS showed the highest numbers of captured oriental moth males (Table 1).

In orchard B (Table 2), sugarcane molasses baited in the three traps captured the lowest number of G. molesta. Pot/ 
TAS, Ajar/TAS, McPhail/GJ, and Pot/GJ sets had the highest total number of captured adult oriental moths. Pot/TAS, Ajar/TAS, and McPhail/GJ captured more G. molesta females. Pot/TAS, Ajar/TAS, and McPhail/GJ has a higher number of captured males.

Taking into account the observations in orchard C, McPhail/GJ, Pot/TAS, and Ajar/TAS captured the highest total number of $G$. molesta specimens. The Pot/TAS group had the highest capture of females, followed by McPhail/GJ and Ajar/TAS. McPhail/GJ, Pot/TAS, Ajar/TAS, and Pot/GJ captured more males.

Ajar/TAS had a higher female ratio captured per trap in the three orchards (Tables 1, 2, and 3). Ajar/TAS captured the largest number of mated females (Tables 1,2 , and 3 ) compared with other trap/attractive combinations, except the orchard A what equaled Pot/GJ (Table 1).

\section{Selectivity to nontarget organisms}

In orchard A, Ajar/TAS and Ajar/SM had the lowest number of captures of nontarget insects. On the other hand, the Mcphail/GJ set had the greatest total capture of nontarget insects, notably belonging to Diptera. The Pot/SM set captured the highest number of insects of the order Hymenoptera, which contained pollinating insects, such as Apis mellifera bees (Table 1).

TAS as a bait in the three types of traps had the lowest number of nontarget insects captured in orchard B. Ajar/TAS set was the most selective (Table 2). McPhail/GJ captured the largest number of insects of the order Diptera. The Pot trap associated with the sugarcane molasses had the largest number of captures of insects of the order Hymenoptera. Orchard C showed similar results to those seen in orchards A and B. Thus, McPhail/SM, Ajar/SM, and Ajar/TAS captured the fewest nontarget insects (Table 3). Pot/SM captured the highest number of insects of the Hymenoptera order; McPhail/GJ obtained the greatest number of insects of the Lepidoptera and Diptera orders. The McPhail/GJ set had the highest total number of captured insects, differing from other treatments. In the three study orchards, the Ajar/TAS set proved to be more selective in the capture of nontarget insects.

\section{Bait persistence}

During the assessed period, in orchard A, the Ajar/TAS set captured the highest total number of $G$. molesta adults at 07,10 , and 14 days after bait preparation. After 14 days, there was a significant drop in the capture of oriental fruit moth females, and at 21 days, there were a lower number of collected adults, unlike the other treatments (Fig 2).

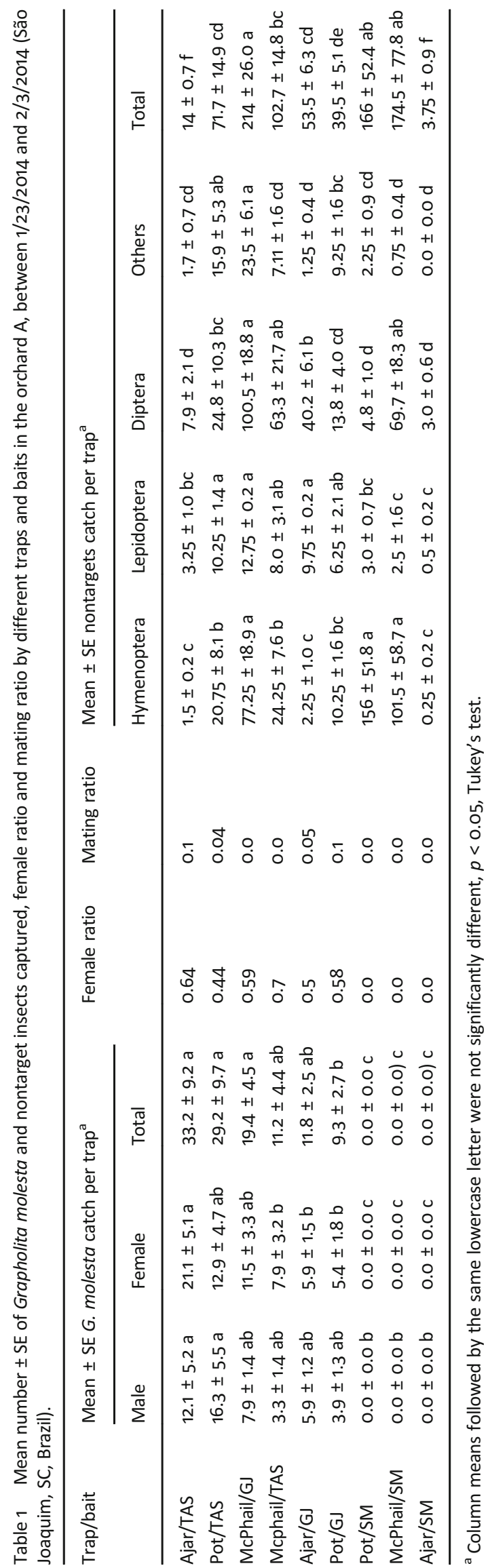



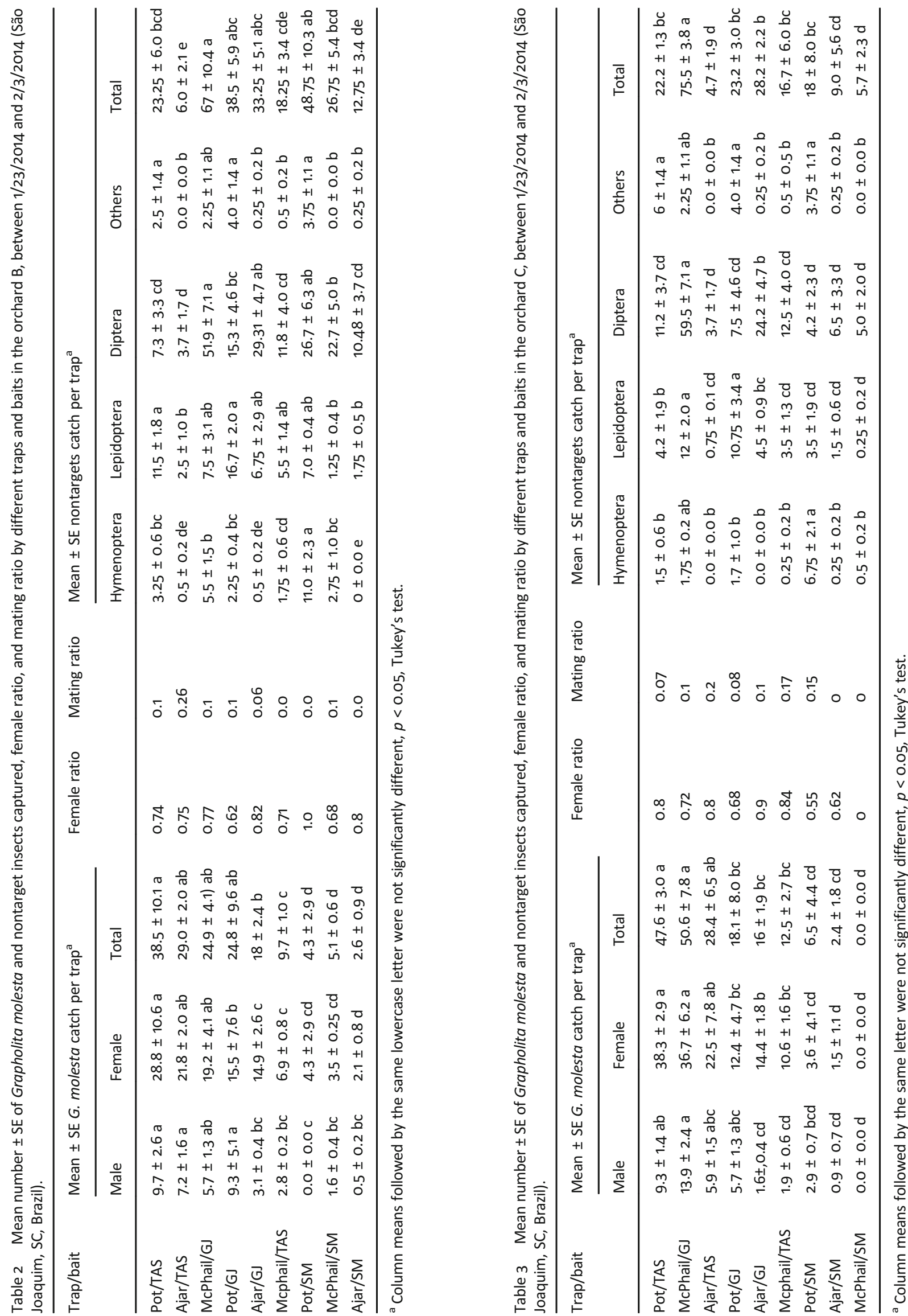


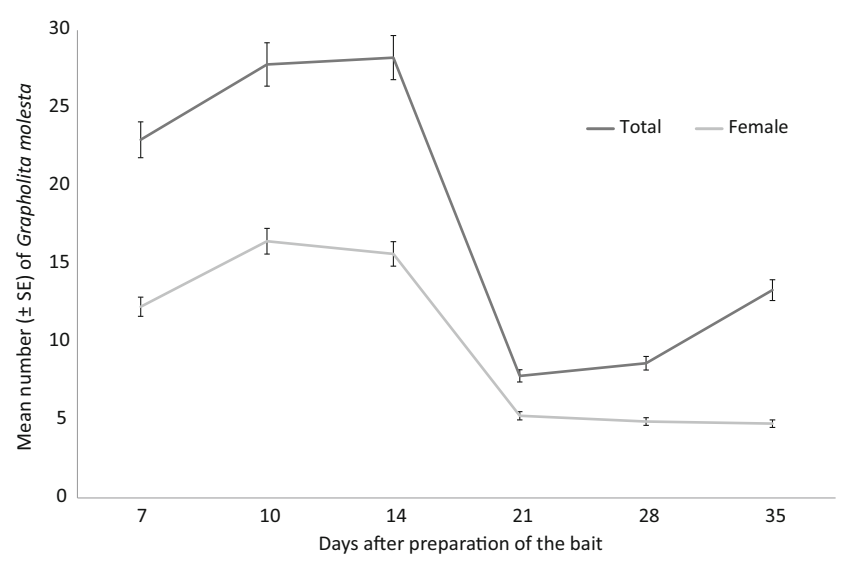

Fig 2 Bait persistence of terpinyl acetate (TAS) (0.05\%) + brown sugar $(8.69 \%)$ for capture of Grapholita molesta in apple orchards between February 27 and March 13, 2014. São Joaquim, SC, Brazil.

\section{Discussion}

Monitoring the insect pests is an important technique for timing the use of control measures, a prerequisite for rational and efficient pest management. Traps with food baits are widely used for many species of insects (El-Sayed et al 2005). During the process of decomposition of organic substances, such as fruit juices, ammonia, and secondary compounds are necessarily released. This may positively influence the capture of $G$. molesta, as most of the adult insects are attracted by specific odors (or groups), which may be released during decomposition (Visser 1986). This may explain the capture of G. molesta adults in traps containing grape juice (25\%).

Lepidoptera use plant volatiles to locate suitable food resources and oviposition (Ansebo et al 2004, Bruce et al 2005). According to Biezanko (1983), insects of the order Lepidoptera are attracted to volatiles emitted by ripe fruits. The host selection for oviposition is essential for the survival of neonate larvae as they show low mobility and difficulty in completing the life cycle if they are not on the host plant (Renwick \& Chew 1994). Terpinyl acetate (TAS) is a secondary metabolite found in some plant species such as mulberry (Morus alba) and proved attractive to silkworm larvae [Bombyx mori (Linnaeus)] (Hamamura 1970). In addition, this compound, when removed from the plant leaves and mixed with a brown sugar solution, was more efficient in attracting G. molesta adults compared with other plant secondary metabolites (Yetter \& Steiner 1931, Dustan 1964). The TAS solution is usually used as a bait in studies on monitoring of G. molesta in peach and apple orchards that use MD in several countries (II'Ichev et al 2002, Kovanci \& Walgenbach 2005, Il'Ichev et al 2009, Cichon et al 2013, Knight et al 2013, Knight et al 2014).

The Ajar/TAS and Pot/TAS sets obtained similar total captures of males and females in the three orchards, showing consistency in attracting and collecting $G$. molesta in different locations. In the period of the experiments, the two sets also captured the highest number of oriental fruit moth adults, corroborating the findings of Cichon et al (2013), in sex-pheromone-treated apple orchards in Argentina. Monitoring studies usually focus on male capture (Arioli et al 2006, Knight et al 2014). However, when there is mating disruption, the capture of females becomes important to evaluate the efficiency of the use of pheromone in the mating disruption. In this study, Ajar/TAS obtained the highest female ratio and the highest mating ratio. That is, Ajar/TAS had a greater capacity to capture mated females. Yetter \& Steiner (1931) reported that TAS was efficient for the capture of mated females.

Two important factors should be taken into account when choosing a trap to capture small insects, such as G. molesta, the first is the ease of handling and observation/ identification of the target insect. In this sense, the Ajar trap was easy to handle and favored the visualization of specimens captured at the time of collection, because it uses a sticky liner and insects are visible to the evaluator, as reported by Cichon et al (2013). Therefore, the authors also claim that this would be the most suitable trap for monitoring that pest.

The second factor is the selectivity of the trap/bait set, because selective traps facilitate the evaluation of the target insect. The sugarcane molasses bait was capture of a large number of insects of the order Hymenoptera, especially when associated with the Pot trap. Although the grape juice captured G. molesta adults, it was not very selective, especially when used in association with McPhail trap, and it attracted and captured a large number of insects of the orders Diptera and Lepidoptera. The massive presence of wing scales of these Lepidoptera made the attractant solution more viscous; thus, it was difficult to visualize oriental fruit moth.

TAS bait associated with the Ajar trap captured fewer nontarget insects than the Pot trap, a result similar to a study reported by Cichon et al (2013). Although TAS is attractive for G. molesta females, TAS is not specific, so probably the combination of Ajar trap and TAS was less attractive to nontarget insects.

In the studies conducted by Myers et al (2009) and by Arioli et al (2006), it was found that trap color is not a significant factor influencing captures of $G$. molesta males. However, white traps tend to capture a greater number of bees than darker traps, e.g., orange ones (Knight and Miliczky 2003, Myers et al 2009, Knight et al 2011). In their work, there were a large number of bees caught in the Pot trap when it was associated with the sugarcane molasses bait and the Pot trap was white. The findings of the present study showed that Ajar/TAS set was considered the best for efficient luring of oriental fruit moth adults in orchards subjected to MD, because these capture the target insect, are easy to handle, and have greater selectivity to nontarget insects. 
During the experiment, it was observed that the Pot trap promotes evaporation of the liquid, especially in periods with high temperatures. In addition, the trap has no barriers to prevent the entry of water, which favors dilution and loss of attractiveness of the bait. These factors affect efficiency and, consequently, the data can be lost if the tank (Pot) overflows; moreover, the collected insects can quickly decompose, and the specimens become difficult to identify (Rothschild 1975).

The sugarcane molasses bait, in three trap models tested, had the lowest rates of capture of $G$. molesta females, reaching zero in two of the three evaluated orchards. This contradicts the report by Campos \& Garcia (2001), who said that sugarcane molasses is the most efficient bait to monitor G. molesta in the orchard of another Rosacea: the peach tree.

Cichon et al (2013) reported that this trap does not require frequent card replacements. However, when assessing the numbers of females captured and their reproductive status, the whole trap sticky liner should be removed and taken to the laboratory to collect the specimens that get stuck to the glue and, thus, preserve insect integrity.

Cichon et al (2013) \& Knight et al (2013) refined the Ajar trap and standardized its bait replenishment schedule. They concluded that bait replacement at intervals of 2 to 3 weeks is an important factor for maintaining maximum trap effectiveness. Similar range to that found in this study, Ajar/TAS enables the luring of population of females in orchards until 14 days after bait preparation. Ideally, the bait solution should be replaced after this time.

Ajar/TAS was the trap with the greatest potential for the monitoring of $G$. molesta in mating disruption apple orchards, because it can detect the presence of G. molesta. Ajar/TAS captured a higher female ratio and mating ratio, when compared to the other sets tested, and was the most selective. In addition, Ajar/TAS provided greater ease of handling and observation of the captured insects. However, further study is needed to investigate pest population fluctuation and/or damage so that this trap/attraction set can be effectively included in a monitoring system.

Acknowledgments The authors are thankful to the project "Development of technologies for the integrated management of pests and apple tree diseases/POMIPEST" of EMBRAPA Uva e Vinho for the provision of financial support.

Electronic supplementary material The online version of this article (doi:10.1007/s13744-017-0517-z) contains supplementary material, which is available to authorized users.

\section{References}

Agosta WC (1990) (ed.) Chemical communication: the language of pheromones. Sci Am Lib, New York, 179
Ansebo L, Coracini MDA, Bengtsson M, Liblikas I, Ramirez M, BorgKarlson AK, Tazin M, Witzgall P (2004) Antennal and behavioural response of codling moth Cydia pomonella to plant volatiles. J Appl Entomol 128:488-493

Arioli CJ, Carvalho GA, Botton M (2006) Monitoramento de Grapholita molesta (Busck) (Lepidoptera: Tortricidae) na cultura do pessegueiro com feromônio sexual sintético. BioAssay 1:1-5

Arioli CJ, Botton M, Mafra-Neto A, Molinari F, Borges R, Pastori PL (2013) Feromônios sexuais no manejo de insetos-praga na fruticultura de clima temperado. Technical Bulletin, Epagri, Florianópolis, p 159

Arioli CJ, Pastori PL, Botton M, Garcia MS, Borges R, Mafra-Neto A (2014) Assessment of SPLAT formulations to control Grapholita molesta (Lepidoptera: Tortricidae) in a Brazilian apple orchard. Chil J Agr Res 74:184-190

Bagnoli B, Espadas AL, Palao JS, Perez BMG, Juan MP, Cascales AP, Ortega M, Sambado P, Lucchi A (2013) Performance of a wine trap device to monitor Lobesia botrana adult populations in Murcia vineyards. Integrated protection and production in viticulture, IOBCWPRS bulletin. Acta Hort 85:145-150

Biezanko CM (1983) Sobre as iscas que se usam para atrair os lepidópteros e algumas outras questões que se relacionam com este assunto. Chácaras e quintais 58:62-63

Botton M, Arioli CJ, Coletta VD (2001) Monitoramento da mariposa oriental Grapholita molesta (Busck, 1916) na cultura do pessegueiro. Embrapa: comunicado técnico, Bento Gonçalves 38:1-4

Bruce TJA, Wadhams LJ, Woodcock CM (2005) Insect host location: a volatile situation. Trends Plant Sci 10:269-274

Campos JV, Garcia FRM (2001) Avaliação de Atrativos na captura de adultos de Grapholita molesta (Busch, 1916) (Lepidoptera: Oletreutidae). Revista da FZVA 7:13-18

Cardé RT, Minks AK (1995) Control of moth pests by mating disruption: successes and constraints. Annu Rev Entomol 40:559-585

Cichon L, Fuentes-Contreras E, Garrido S, Lago J, Barros-Parada W, Basoalto E, Hilton R, Knight A (2013) Monitoring oriental fruit moth (Lepidoptera: Tortricidae) with sticky traps baited with terpinyl acetate and sex pheromone. J Appl Entomol 137:275-281

Dustan G (1964) Mating behaviour of the oriental fruit moth Grapholitha molesta (Busck) (Lepidoptera: Olethreutidae). Can Entomol 96:10871093

El-Sayed AM, Heppelthwaite VJ, Manning LM, Gibb AR, Suckling DM (2005) Volatile constituents of fermented sugar baits and their attraction to lepidopteran species. J Agric Food Chem 53:953-958

Evenden ML, Mclaughlin JR (2004) Factors influencing the effectiveness of an attracticide formulation against the oriental fruit moth, Grapholita molesta. Entomol Exp Appl 112:89-97

Hamamura Y (1970) The substances that control the feeding behaviour and the growth of the silkworm Bombyx mori. In: Wood DL, Silverstein RM, Nakajima M (eds) Control of insect behavior by natural products. Academic Press, New York

Howell JF (1991) Reproductive biology. In: Der Geest LPS V, Evenhuis HH (eds) Tortricid pests. Their biology, natural enemies and control. Elsevier, Amsterdam, pp 174-257

IIIIchev AL, Gut L, Williams DG, Hossain MS, Jerie PH (2002) Area-wide approach for improved control of oriental fruit moth Grapholita molesta (Busck) (Lepidoptera: Tortricidae) by mating disruption. Gen Appl Entomol 31:7-15

Il'Ichev AL, Kugimiya S, Williams DG, Takabayashi J (2009) Volatile compounds from young peach shoots attract males of oriental fruit moth in the field. J Plant Int 4:289-294

Knight A, Miliczky E (2003) Influence of trap colour on the capture of codling moth (Lepidoptera: Tortricidae), honeybees, and non-target flies. J Entomol Soc Brit Col 100:65-70

Knight A, Pickel C, Hawkins L, Abbott C, Hansen R, Hull L (2011) Monitoring oriental fruit moth (Lepidoptera: Tortricidae) and peach twig borer (Lepidoptera: Gelechiidae) with clear delta-shaped traps. J Appl Entomol 135:106-114 
Knight A, Basoalto $E$, Hilton R, Molinari F, Zoller B, Hansen R, Hull L (2013) Monitoring oriental fruit moth (Lepidoptera: Tortricidae) with the Ajar trap in orchards under mating disruption. J Appl Entomol 137: 650-660

Knight A, Cichon L, Lago J, Fuentes-Contreras E, Barros-Parada W, Hull L, Basoalto E (2014) Monitoring oriental fruit moth and codling moth (Lepidoptera: Tortricidae) with combinations of pheromones and kairomones. J Appl Entomol 138:783-794

Kovanci OB, Walgenbach JF (2005) Monitoring the oriental fruit moth with pheromone and bait traps in apple orchards under different management regimes. Int J Pest Manag 24:273-279

Kovanci OB, Walgenbach JF, Kennedy GG, Schal C (2005) Effects of application rate and interval on the efficacy of sprayable pheromone for mating disruption of the oriental fruit moth Grapholita molesta. Phytoparasitica 33:334-342

Mapa (2013) Ministério da Agricultura, Pecuária e Abastecimento. Instrução Normativa $n^{\circ} 1$, de 4 de janeiro de 2013. Dispõe sobre o plano nacional de controle de resíduos e contaminantes em produtos de origem vegetal no ano-safra 2011/2012. Diário Oficial da União, Brasília, 1:10p

Morais RM de, Redaelli LR, Santana J (2011) Anatomia comparada dos órgãos internos de reprodução de Grapholita molesta (Busck, 1916) (Lepidoptera: Tortricidae). Biot 22:59-67

Myers CT, Krawczyk G, Agnello AM (2009) Response of tortricid moths and non-target insects to pheromone trap color in commercial apple orchards. J Entomol Sci, 44-69

Nora I, Hickel E (2006) Pragas da macieira. In: A Cultura da Macieira. Epagri, Flori anópolis, 463-486

Pastori PL, Arioli CJ, Botton M, Monteiro LB, Stoltman L, Mafra-Neto A (2012) Integrated control of two tortricid (Lepidoptera) pests in apple orchards with sex pheromones and insecticides. Rev Colomb Entomol 38:224-230

Phillips JHH (1973) Monitoring for oriental fruit moth with synthetic sex pheromone. Environ Entomol 2:1039-1042

Pim - Produção Integrada de Maçã (2015) Grade de Agrotóxicos e Agroquímicos Ciclo 2015/2016. Agapomi. [WWW document] URL http://agapomi.com.br/wp-content/uploads/Agapomi-Grade-deAgroqu\%C3\%ADmicos-ciclo-2015-16_fim.pd

$R$ : A language and environment for statistical computing (2014) R Foundation for Statistical Computing, Vienna, Austria. ISBN 3900051-07-0, URL http://www.R-project.org/. R development core team version 3.1.0

Renwick JAA, Chew FS (1994) Oviposition behavior in Lepidoptera. Annu Rev Entomol 39:377-400

Rice RE, Kirsch P (1990) Mating disruption of the oriental fruit moth in the United States. In: Behavior-modifying Chemicals for Pest Management: applications of pheromones and other attractants. (Eds) by Silverstein RL, Inscoe RM, Marcel Dekker MN, Ridgeway, New York, 193-211

Rothschild GHL (1975) Control of oriental fruit moth (Cydia molesta (Busck) (Lepidoptera, Tortricidae)) with synthetic female pheromone. B Entomol Res 65:473-490

Strapasson P (2012) Percepção química de Grapholita molesta (Busck) (Lepidoptera: Tortricidae) a substâncias alimentares e voláteis de maçã. Ph.D. Thesis Universidade Federal do Paraná, Curitiba

Visser JH (1986) Host odor perception in phytophagous insects. Annu Rev Entomol 31:121-144

Yetter WP, Steiner LF (1931) A preliminary report on large-scale bait trapping of the oriental fruit moth in Indiana and Georgia. J Econ Entomol 24:1181-1197 